\title{
Polymorphisms in the Estrogen Receptor Alpha Gene and Mammographic Density Result Study in Brazilian Women
} Marilene Alícia Souza ${ }^{1 *}$, Angela Maggio da Fonseca ${ }^{1}$, Vicente Renato Bagnoli' ${ }^{1}$, Nestor de Barros ${ }^{1}$, Victor Hugo Souza Hortense ${ }^{2}$, Solange
Oliveira Braga Franzolin ${ }^{3}$, José Maria Soares $\mathrm{Jr}^{1}$ and Edmund Chada Baracat ${ }^{1}$

${ }^{1}$ Department of Obstetrics Gynecology, Faculty of Medicine, University of São Paulo (HC-FMUSP), Brazil

${ }^{2}$ Department of Radiology/Mammography, Faculty of Medicine, University of São Paulo (HC-FMUSP), Brazil

${ }^{3}$ Faculty of Medicine, Pontifical Catholic University of Paraná (FM-PUC), Brazil

${ }^{4}$ Faculty of Medicine, State University of São Paulo (UNESP), Brazil

\begin{abstract}
The estrogen receptor $(E R)$ is a ligand-activated transcription factor that mediates the actions of the estrogen in target tissues. Several ERa gene polymorphisms are associated with changes in the receptor expression and function. The aim of this study is to verify the hypothesis that the ERa gene polymorphisms could be associated with high mammographic density(HMD), a well known independent risk factor for breast cancer ( BC ) in a casecontrol study carried out in the city of São Paulo (SP, Brazil) from 2010 to 2013 . Two ERa gene polymorphisms named Pvull and Xbal was examined in 308 cases and 155 controls. The Pvull polymorphism was associated with an increased risk of having high mammographic density (HMD) post menopause, after adjustment for other risk factors, the odds ratio for pp genotypes was 1.75 (confidence interval of 95\% Cl 95\%=1.10-2.79) compared with the genotypes PP and Pp. The Xbal polymorphism was also associated with a high risk of HMD, but not statistically significant, odds ratio for $x x$ genotype was $1.31(95 \% \mathrm{Cl}=0.7$ to 1.9$)$. No apparent synergistic effects of these two polymorphisms were identified. It was concluded that the Pvull polymorphism in the gene ERa was associated with an increasing chance of have HMD, a strong risk factor for $\mathrm{BC}$. Thus recognizing these risk factors will be of great importance in the analyses of individual susceptibility to $B C$, in both the study of the response to various drugs and the prognosis.
\end{abstract}

Keywords: Breast neoplasms; Estrogen receptors; Genetic polymorphism; Mammography; Risk factors

\section{Introduction}

Estrogens affect the growth, differentiation and function of many target tissues including breast, uterus, vagina, ovary, testicles, epididymis, and prostate [1]. The biological effect of the estrogens such as growth and differentiation of normal breast tissue is mediated primarily through high affinity binding to its ER. The ERs are intranuclear proteins that possess a binding domain to the estrogen and a binding domain with the DNA [2]. There are two types of ERs ( $\alpha$ and $\beta$ ). The ER $\alpha$ gene is located [3] on chromosome 6q25.1, and the ER $\beta$ gene is located on chromosome $14 \mathrm{q} 22-24$. Among the steroid receptors the ERa and the progesterone receptors (PR) are of special interest because their protein levels are elevated in malignant breast cells [4-6]. Both ER and PR prove to be significant prognostic factors for BC [7]. Therefore the inhibition of Era has become a major strategy for the prevention and treatment of $\mathrm{BC}[8]$.

The combination of ERa gene polymorphisms and the risk of diseases, including $\mathrm{BC}$ have become subject of growing interest. Thus, several studies have indicated that variations in the DNA sequence of the ER $\alpha$ gene increase the risk of developing BC and HMD after menopause. Some studies are summarized in Tables 1 and 2.

The studies of polymorphisms related to diseases are tools that may have direct implication of great importance in the analysis of individual susceptibility to $\mathrm{BC}$ in the study of response to various drugs and prognosis. The ultimate goal of these strategies is to reduce the anxiety of the patients and greatly improve the approach and management of a woman with or without risk, facilitating the implementation, planning and the adoption of preventive strategies.

This article presents the results of the case-control study in the city of São Paulo, that examined the association of the polymorphisms in the genes $E R \alpha-P v u I I$ and $E R \alpha-X b a I$ with the risk of high mammographic density after menopause. The associations of these polymorphisms with other risk factors for breast cancer were also evaluated.

\section{Methods}

Case-control study that included 308 women with $\mathrm{HMD}$ (for more than $50 \%$ density) and 155 controls(to $50 \%$ density or less) evaluated by computerized objective method [25], aged 45-65, without menstruation or hormone therapy for at least 1 year, without previous $\mathrm{BC}$ and ovarian cancer. Initially, the patients were selected in a subjective way by the standard ACR-BIRADS', by a unique reader (the head) from the Institute of Radiology, Hospital das Clinicas, Faculdade de Medicina, Universidade de São Paulo (HC-FMUSP), São Paulo, Brazil, from January 2010 to March 2013. The selected patients were evaluated again, now objectively, by another reader as described by Boyd et al. 2013 [25]. The study was approved by the Ethics Committee for Analysis of Research Projects - CAPPesq the HC-FMUSP, and all women signed informed consent. It was characterized in the clinical

*Corresponding author: Marilene A Souza, Rua Azarias Leite, 12-22, Bauru, SP, CEP 17010250, Brazil, Tel: 551432236538; Fax: 551432236538; E-mail: marilenealicia@hotmail.com

Received November 24, 2013; Accepted December 23, 2013; Published December 31, 2013

Citation: Souza MA, Fonseca AM, Bagnoli VR, de Barros N, Hortense VHS, et al. (2013) Polymorphisms in the Estrogen Receptor Alpha Gene and Mammographic Density Result Study in Brazilian Women. J Cancer Sci Ther 5: 446-451. doi:10.4172/1948-5956.1000239

Copyright: (c) 2013 Souza MA, et al. This is an open-access article distributed under the terms of the Creative Commons Attribution License, which permits unrestricted use, distribution, and reproduction in any medium, provided the original author and source are credited. 
Citation: Souza MA, Fonseca AM, Bagnoli VR, de Barros N, Hortense VHS, et al. (2013) Polymorphisms in the Estrogen Receptor Alpha Gene and Mammographic Density Result Study in Brazilian Women. J Cancer Sci Ther 5: 446-451. doi:10.4172/1948-5956.1000239

\begin{tabular}{|c|c|c|c|c|c|c|}
\hline Genotype & Allele & Country & Type and size of the study & Association & OR/RR & References \\
\hline \multirow[t]{13}{*}{$\begin{array}{l}\text { ERa-397 T/C } \\
\text { Pvull }\end{array}$} & TT & $\begin{array}{l}\text { USA pre- } \\
\text { andpostmenopausal }\end{array}$ & Only Cases/Case Control 257/140 & Diagnosis in younger women & & Yaich et al. [9] \\
\hline & TT & Shanghai, China & Case/control 1069/1166 & $\uparrow$ risk for breast cancer & $\begin{array}{l}\text { OR: } 1.4 \\
\text { IC } 95 \%: 1.1-1.8 \\
p=0.042\end{array}$ & Cai et al. [10] \\
\hline & TT & Netherlands & $\begin{array}{l}\text { Case/control } \\
380 / 422\end{array}$ & $\uparrow$ risk for breast cancer & $\begin{array}{l}\text { RR: } 1.5 \\
\text { IC 95\%: } 0.94-2.42\end{array}$ & $\begin{array}{l}\text { Onland-Moret et } \\
\text { al. [11] }\end{array}$ \\
\hline & TT & $\begin{array}{l}\text { China } \\
25 \text { a } 55 \text { years-old }\end{array}$ & $\begin{array}{l}\text { Case/control } \\
259 / 278\end{array}$ & $\begin{array}{l}\uparrow \text { risk of breast cancer in } \\
\text { women with a positive family } \\
\text { history }\end{array}$ & $\begin{array}{l}\text { OR: } 3.04 \\
\text { IC } 95 \%: 0.73-12.67\end{array}$ & Shen et al. [12] \\
\hline & TT & $\begin{array}{l}\text { Spain } \\
26 \text { to } 86 \text { years-old }\end{array}$ & $\begin{array}{l}\text { Case/control } \\
444 / 704\end{array}$ & $\begin{array}{l}\uparrow \text { risk of breast cancer in } \\
\text { women with a positive family } \\
\text { history }\end{array}$ & $\begin{array}{l}\text { OR: } 3.81 \\
\text { IC } 95 \%: 1.25-11.6\end{array}$ & $\begin{array}{l}\text { Gonzalez-Mancha } \\
\text { et al. [13] }\end{array}$ \\
\hline & TT & $\begin{array}{l}\text { Netherlands } \\
55 \text { yearsor more }\end{array}$ & $\begin{array}{l}\text { Case/control } \\
190 / 3513\end{array}$ & $\begin{array}{l}\uparrow \text { risk of breast cancer in } \\
\text { women after menopause }\end{array}$ & $\begin{array}{l}\text { OR: } 1.4 \\
\text { IC } 95 \%: 0.8-2.2\end{array}$ & $\begin{array}{l}\text { Ladd et al. } 2007 \\
\text { [14] }\end{array}$ \\
\hline & TT & $\begin{array}{l}\text { USA peri-menopause } 42 \text { to } \\
52 \text { years-old }\end{array}$ & $\begin{array}{l}\text { longitudinal cohort } \\
451\end{array}$ & $\begin{array}{l}\uparrow \text { Increased mammographic } \\
\text { density in white women }\end{array}$ & $\begin{array}{l}7.0 \% \\
p=0.01\end{array}$ & Crandall et al. [15] \\
\hline & TT & Brazil After-menopause & Only cases 308 women & Mammographic density $>50 \%$ & $\begin{array}{l}\mathrm{TT}=32.14 \% \text { greater } \\
\text { than } \mathrm{CC}=20.13 \%\end{array}$ & Souza et al. [16] \\
\hline & TT/TC & $\begin{array}{l}\text { Netherlands and England } \\
\text { After-menopause }\end{array}$ & $\begin{array}{l}\text { Population Cohort prospective case/ } \\
\text { control ( } 795 \text { with HT/781 with no HT) }\end{array}$ & $\begin{array}{l}\uparrow \text { Increased mammographic } \\
\text { density only in HT users }\end{array}$ & $\begin{array}{l}2.24 \% \\
p<0.01\end{array}$ & $\begin{array}{l}\text { van Duijnhoven et } \\
\text { al. [17] }\end{array}$ \\
\hline & TC & Netherlands & Caso/controle380/422 & $\uparrow$ risk for $B C$ & $\begin{array}{l}\text { OR: } 1.14 \\
\text { IC } 95 \%: 1.00-1.32\end{array}$ & $\begin{array}{l}\text { Onland-Moret et } \\
\text { al. [11] }\end{array}$ \\
\hline & $\mathrm{TC}$ & $\begin{array}{l}\text { China } \\
25-55 \text { anos }\end{array}$ & $\begin{array}{l}\text { Case/control } \\
259 / 278\end{array}$ & $\begin{array}{l}\uparrow \text { risk for BC(with family } \\
\text { history) }\end{array}$ & $\begin{array}{l}\text { OR: } 2.46 \\
\text { IC } 95 \%: 0.61-9.88\end{array}$ & Shen et al. [12] \\
\hline & $\mathrm{CC}$ & $\begin{array}{l}\text { Shanghai, China } \\
22-64 \text { years-old }\end{array}$ & $\begin{array}{l}\text { ProspectivePopulation Cohort } \\
1459 \text { cases }\end{array}$ & $\begin{array}{l}\text { RE negative expression; } \\
\text { worse prognosis for breast } \\
\text { cancer }\end{array}$ & $\begin{array}{l}\text { OR: } 3.30 \\
\text { IC } 95 \%: 1.42-7.69\end{array}$ & Boyapatti et al. [5] \\
\hline & $\mathrm{CC}$ & $\begin{array}{l}\text { Netherlands and England } \\
\text { After-menopause }\end{array}$ & $\begin{array}{l}\text { Population Cohort prospective case/ } \\
\text { control }[795 / 781]\end{array}$ & $\begin{array}{l}\text { Mammographic density } \\
\text { without changes in user HT }\end{array}$ & $\begin{array}{l}0.90 \% \\
p=0.47\end{array}$ & $\begin{array}{l}\text { van Duijnhoven et } \\
\text { al. [17] }\end{array}$ \\
\hline
\end{tabular}

Table 1: Association studies of the ERa-397 gene polymorphism Pvull C/T with BC and/or risk factors for disease.

history and physical examination: age at menarche and menopause, parity, age at first birth, family history of breast cancer (FHBC), smoking, alcohol intake and body mass index (BMI). Peripheral blood samples were obtained for genomic DNA extraction and determination of polymorphisms in question.

The genomic DNA was extracted from peripheral blood using QIAamp DNA Blood Mini Kit (Qiagen), following manufacturer instructions. After DNA quality and integrity evaluation were performed PCR-RFLP assay for Estrogen Receptor PvuII and XbaI polymorphism analysis as described by Herrington et al. 2002 [26]. The laboratory was blinded on the subject identification.

Hardy-Weinberg Equilibrium (H_W) was used to verify if the genotype frequencies of PvuII and XbaI polymorphisms in our population were in genetic equilibrium. Simple mathematical model $[(\mathrm{p}+\mathrm{q}) 2=\mathrm{p} 2+2 \mathrm{pq}+\mathrm{q} 2]$ used to calculate genotype frequencies from allele frequencies.

Statistical analysis: The data were described using average, standard deviation (sd), absolute frequency (n) and relative frequency (\%). To verify the association between qualitative variables with the mammographic density was used the chi-square $\left(X^{2}\right)$. For comparison between the groups of HMDand controls as quantitative variables was used the Kolmogorov-Smirnov Test to verify the normality of the data, as these are not normally distributed in all groups, was used the nonparametric Mann-Whitney Test for comparison between groups. To verify the relationship of the variables with the occurrence of high mammographic density was used Multivariate Logistic Regression model stepwise backward. The variables that entered in the model were those presented in the bivariate analyzes values $p<0.20$. In all statistical tests were adopted a significance level of $5 \%(\mathrm{p}<0.05)$.

\section{Results}

The distributions of selected demographic characteristics that are the main risk factors for breast cancer are presented in Table 3 . It was observed elevated risk of HMD for the main risk factors that have been reported in other previous studies [20,16].

The risk of having HMD was also elevated for younger women, lower WC, fewer pregnancies, higher age at having first birth, high number of women with a FHBC. It was not observed any apparent modification effect for other indicators of exposure to endogenous estrogens and lifestyle factors. In our study, the sample consisted of postmenopausal women, aged 45-65 years.

The allele frequencies of $E R \alpha-P v u I I$ and $E R \alpha-X b a I$ in both groups were similar to those reported in previous studies [16,17,20,27-29].

Regarding the genotype, $21.5 \%$ of controls and $32.5 \%$ of cases were mutated homozygous (pp), and $28.5 \%$ of controls and $19.8 \%$ of cases were wild homozygous (PP), with statistically significant difference $\left(\mathrm{X}^{2}=7.42, \mathrm{p}=0.024\right)$. OR adjusted for $\mathrm{pp}$ genotype was $1.75(95 \%$ $\mathrm{CI}=1.10$ to 2.79 ) compared with $\mathrm{PP}$ and Pp genotype. There were not any significant difference in allele frequency or genotype polymorphism $E R \alpha-X b a I$ between controls and cases (Table 4).

When the two ERa polymorphisms were analyzed together, no synergistic effect was consistently noted.

Additional analyzes (Multivariate Logistic Regression) were performed to evaluate the independent risk factors for HMD. From all clinical characteristics analyzed, entered only those presented in the bivariate analyzes values $\mathrm{p}<0.20$ were included in the model: the Pvull polymorphism of the ERa gene; indicators of exposure to endogenous estrogen: age at menarche, menopause, time after menopause, 
Citation: Souza MA, Fonseca AM, Bagnoli VR, de Barros N, Hortense VHS, et al. (2013) Polymorphisms in the Estrogen Receptor Alpha Gene and Mammographic Density Result Study in Brazilian Women. J Cancer Sci Ther 5: 446-451. doi:10.4172/1948-5956.1000239

\begin{tabular}{|c|c|c|c|c|c|c|}
\hline Genotype & Allele & Population & $\begin{array}{l}\text { Type and size of the } \\
\text { study }\end{array}$ & Association & OR/RR & References \\
\hline \multirow[t]{11}{*}{ ERa351 Xbal A/G } & AA & $\begin{array}{l}\text { Norway } 27 \text { to } 94 \text { years- } \\
\text { old }\end{array}$ & Case/control 360/672 & $\uparrow$ risk for breast cancer after menopause & $\begin{array}{l}\text { OR: } 2.02 \\
\text { IC } 95 \%: 0.96-4.31\end{array}$ & Andersen et al. [18] \\
\hline & AA & Korea & Case/control 205/205 & $\uparrow$ risk for breastcancer & $\begin{array}{l}\text { OR: } 2.38 \\
\text { IC } 95 \%: 1.58-3.58\end{array}$ & Shin et al. [6] \\
\hline & AA & Korea & Case/control 205/205 & $\uparrow$ risk for breast cancer in nulliparous & $\begin{array}{l}\text { RR: } 4.0 \\
\text { IC } 95 \%: 1.9-8.8\end{array}$ & Shin et al. [6] \\
\hline & AA & $\begin{array}{l}\text { Netherlands and England } \\
\text { After-menopause }\end{array}$ & $\begin{array}{l}\text { Cohort prospective } 791 \\
\text { with HT/781 no HT }\end{array}$ & $\uparrow$ mammographic density in HT users & $\begin{array}{l}2.20 \% \\
p<0.01\end{array}$ & $\begin{array}{l}\text { van Duijnhoven et } \\
\text { al. [17] }\end{array}$ \\
\hline & AA & China & & $\uparrow$ risk for breastcancer & $\begin{array}{l}\text { OR: } 6.88 \\
\text { IC } 95 \%: 0.80-59.15 \\
p=0.079\end{array}$ & Hu et al. [19] \\
\hline & AA & $\begin{array}{l}\text { China } \\
25-55 \text { years-old }\end{array}$ & Case/control & $\begin{array}{l}\uparrow \text { risk for breast cancer, with positive } \\
\text { family history }\end{array}$ & $\begin{array}{l}\text { OR: } 4.20 \\
\text { IC } 95 \%: 0.65-27.28\end{array}$ & Shen et al. [12] \\
\hline & AA & $\begin{array}{l}\text { Netherlands } \\
55 \text { yearsor more }\end{array}$ & Case/control 190/3513 & $\begin{array}{l}\uparrow \text { risk for breast cancer in women after } \\
\text { menopause }\end{array}$ & $\begin{array}{l}\text { OR: } 1.3 \\
\text { IC } 95 \%: 0.7-2.2\end{array}$ & Ladd et al. [14] \\
\hline & AA & $\begin{array}{l}\text { Brazil } \\
\text { After-menopause }\end{array}$ & $\begin{array}{l}\text { Prospective } \\
120\end{array}$ & $\uparrow$ higherbreastdensity & $\begin{array}{l}\text { OR: } 2.34 \\
\text { IC } 95 \%: 1.06-5.16 \\
p=0.03\end{array}$ & Ramos et al. [20] \\
\hline & & England & $\begin{array}{l}\text { Systematic review of } \\
\text { case-control studies }\end{array}$ & Nonsignificantdifference & $P=0.06$ & Dunning et al. [21] \\
\hline & AA & Pakistan, $15-65$ years-old & Case/control 100/100 & $\uparrow$ of the risk of BC post menopouse & $\begin{array}{l}\text { AA } 45 \% \\
\text { greater than GG } \\
p<0.01\end{array}$ & Javed et al. [22] \\
\hline & AA & BrazilAfter-menoppausa & $\begin{array}{l}\text { Only cases } \\
308 \text { women }\end{array}$ & Mammographicdensity $>50 \%$ & $\begin{array}{l}\text { AA } 33.44 \% \\
\text { greaterthan GG } \\
16.56 \%\end{array}$ & Souza et al. [16] \\
\hline \multirow[t]{6}{*}{$\begin{array}{l}\text { HaplotypXbal- } \\
\text { C975 } \rightarrow \mathbf{G}\end{array}$} & & $\begin{array}{l}\text { Sweden after- } \\
\text { menoppausa }\end{array}$ & Case/control 1556/1512 & $\begin{array}{l}\uparrow \text { risk of breast cancer in postmenopausal } \\
\text { and obese women }\end{array}$ & $\begin{array}{l}\text { OR=1.48 } \\
\text { IC } 95 \%: 1.17-1.88\end{array}$ & Wedren et al. [23] \\
\hline & AG & Norway 27-94 years-old & Case/control 360/672 & $\uparrow$ risk for breastcancer & $\begin{array}{l}\text { OR: } 2.00 \\
\text { IC 95\%: } 0.92-4.37\end{array}$ & Andersen et al. [18] \\
\hline & GG & $\begin{array}{l}\text { USA, Caucasian greater } \\
\text { than } 65 \text { years-old }\end{array}$ & Case/control 393/790 & $\downarrow$ risk for breastcancer & $\begin{array}{l}\text { OR } 0.82 \\
\text { IC 95\%: } 0.68-1.00 \\
P=0.04\end{array}$ & Wang et al. [24] \\
\hline & GG & $\begin{array}{l}\text { Netherlands and England } \\
\text { After-menopause }\end{array}$ & $\begin{array}{l}\text { Prospective Cohort } 795 \\
\text { with HT/781 no HT }\end{array}$ & $\begin{array}{l}\text { Mammographic density without changes } \\
\text { in users of HT }\end{array}$ & $\begin{array}{l}0.65 \% \\
p=0.70\end{array}$ & $\begin{array}{l}\text { van Duijnhoven et } \\
\text { al. [17] }\end{array}$ \\
\hline & A & China & Case/control 114/121 & $\uparrow$ risk for breastcancer & $\begin{array}{l}\text { OR: } 1.4 \\
\text { IC } 95 \%: 1.0-1.9\end{array}$ & Hu et al. [19] \\
\hline & G & Korea & Case/control 205/205 & $\begin{array}{l}\downarrow \text { risk for breast cancer in } \\
\text { postmenopausal }\end{array}$ & $\begin{array}{l}\text { RR: } 0.3 \\
\text { IC } 95 \%: 0.1-0.5\end{array}$ & Shin et al. [6] \\
\hline
\end{tabular}

Table 2: Association studies of the ERa-351 Xbal A/G gene polymorphism with BC and/or risk factors for disease.

\begin{tabular}{|c|c|c|c|c|c|c|c|}
\hline \multirow{3}{*}{$\begin{array}{l}\text { Quantitativevariables } \\
\text { Age }\end{array}$} & \multirow{3}{*}{ Average } & \multirow{2}{*}{\multicolumn{2}{|c|}{$\begin{array}{c}\text { Controls } \\
\text { Dp }\end{array}$}} & \multicolumn{2}{|c|}{ HMD } & \multirow[b]{2}{*}{ Z } & \multirow[b]{2}{*}{$\mathbf{P}$} \\
\hline & & & & Average & Dp & & \\
\hline & & 58.16 & 4.61 & 56.31 & 5.42 & 3.40 & $0.001^{*}$ \\
\hline Wast circunference & 95.06 & \multicolumn{2}{|c|}{11.13} & 89.47 & 10.83 & 5.04 & $<0.001^{*}$ \\
\hline Number of Pregnancies & 3.63 & \multicolumn{2}{|c|}{2.56} & 2.46 & 1.83 & 4.62 & $<0.001^{*}$ \\
\hline Number of Births & & 2.84 & 1.98 & 1.99 & 1.54 & 4.37 & $<0.001^{*}$ \\
\hline Number of Abortions & & 0.79 & 1.20 & 0.48 & 0.87 & 2.93 & $0.003^{*}$ \\
\hline Date of last menstruation & & 46.83 & 6.26 & 46.45 & 6.33 & 0.49 & 0.621 \\
\hline Age at first birth & & 21.88 & 5.16 & 24.04 & 6.04 & 3.61 & $<0.001^{*}$ \\
\hline Menarche & & 12.87 & 1.78 & 13.17 & 1.78 & 1.66 & 0.096 \\
\hline Time after menopause & & 11.33 & 6.42 & 9.85 & 7.38 & 2.69 & $0.007^{*}$ \\
\hline Qualitative variables & n & \multicolumn{2}{|c|}{$\%$} & $n$ & $\%$ & $x^{2}$ & $\mathbf{P}$ \\
\hline \multirow[t]{2}{*}{ BMI } & Normal/overweight & 81 & 52.3 & 195 & 63.3 & 5.23 & $0.022^{*}$ \\
\hline & Obese & 74 & 47.7 & 113 & 36.7 & & \\
\hline \multirow[t]{2}{*}{ Smoke } & No & 140 & 90.3 & 264 & 85.7 & 1.97 & 0.161 \\
\hline & Yes & 15 & 9.7 & 44 & 14.3 & & \\
\hline \multirow[t]{2}{*}{ Alcohol intake } & No & 137 & 88.4 & 258 & 83.8 & 1.76 & 0.185 \\
\hline & Yes & 18 & 11.6 & 50 & 16.2 & & \\
\hline \multirow[t]{2}{*}{ Metabolic syndrome } & No & 104 & 67.1 & 220 & 71.4 & 0.92 & 0.337 \\
\hline & Yes & 51 & 32.9 & 88 & 28.6 & & \\
\hline
\end{tabular}

Quantitative variables *Statistically significant difference $[p<0.05]$

Nonparametric Mann-Whitney test

*Qualitative variables: statistically significant difference $[p<0.05]$

Chi-square test

Table 3: Comparison between the two groups of Mammographic Density: HMD and controls in quantitative and qualitative variables. 


\begin{tabular}{|c|c|c|c|c|c|}
\hline \multirow{2}{*}{ High mammographic density } & \multicolumn{3}{|c|}{ Pvull } & \multirow[b]{2}{*}{ Total } & \\
\hline & $\mathrm{Pp}$ & $\mathrm{Pp}$ & PP & & \\
\hline \multirow{2}{*}{ No } & 72 & 31 & 41 & 144 & $X^{2}=7.42$ \\
\hline & $50.0 \%$ & $21.5 \%$ & $28.5 \%$ & $100.0 \%$ & $p=0.024^{*}$ \\
\hline \multirow{2}{*}{ Yes } & 147 & 100 & 61 & 308 & $\mathrm{OR}=1.75$ \\
\hline & $47.7 \%$ & $32.5 \%$ & $19.8 \%$ & $100.0 \%$ & IC $95 \%=1.10-2.79$ \\
\hline \multirow{4}{*}{ Total } & 219 & 131 & 102 & 452 & \\
\hline & $48.5 \%$ & $29.0 \%$ & $22.6 \%$ & $100.0 \%$ & \\
\hline & \multicolumn{3}{|c|}{ Xbal } & & \\
\hline & $X x$ & $X x$ & $x x$ & Total & \\
\hline \multirow{2}{*}{ No } & 74 & 40 & 30 & 144 & $X^{2}=2.03$ \\
\hline & $51.4 \%$ & $27.8 \%$ & $20.8 \%$ & $100.0 \%$ & $p=0.362$ \\
\hline \multirow{2}{*}{ Yes } & 154 & 103 & 51 & 308 & $\mathrm{OR}=1.31$ \\
\hline & $50.0 \%$ & $33.4 \%$ & $16.6 \%$ & $100.0 \%$ & IC $95 \%=0.85-2.02$ \\
\hline \multirow{2}{*}{ Total } & 228 & 143 & 81 & 452 & \\
\hline & $50.4 \%$ & $31.6 \%$ & $17.9 \%$ & $100.0 \%$ & \\
\hline
\end{tabular}

Table 4: Association between mammographic densities and polymorphisms Pvull and Xbal.

number of pregnancies, age at first birth, number of births, number of abortions, FHBC, BMI, waist circumference (WC), and the variables that characterize the sample (age, race, alcohol intake, smoking). The risk associated with the $\mathrm{p}$ allele of the PvuII was high in all strata. It was observed an increased risk of having HMD for women with younger age, smaller WC, fewer pregnancies, old age at having the first birth, the higher number of women with a FHBC. There was no apparent modification effect for the other indicators of exposure to endogenous estrogens.

Likewise, it was performed the association between the $\mathrm{x}$ allele of the $\mathrm{XbaI}$ and the same independent variables that characterize the sample, but no results confirmed the association.

\section{Discussion}

The association of ERa gene polymorphisms with the risk of $\mathrm{BC}$ draws attention because the ER functions as a regulator of the hormone dependent transcription, which plays a significant role in the development of $B C$ [10]. Indeed, approximately two thirds of $\mathrm{BC}$ expresses the estrogen receptor alpha. Epidemiologic studies also correlate steroid hormones to changes the MD, and have examined whether variations in genes that regulate the biosynthesis and hormonal metabolism could explain individual differences in MD. The ER gene, located in the long arm of chromosome 6q25, has been associated to HMD in many studies, due to its importance in the development, progression and prognosis of BC. Several polymorphisms of ER $\alpha$ gene have been reported, with the PvuII and XbaI - located in intron 1 of the ERa gene with 50 base pairs between them - being the most studied. Several diseases, including BC $[6,9,10,18,30]$, endometrial cancer [31], Alzheimer's disease [32], obesity [33,34], endometriosis [35], leiomyomas [36] and bone mineral density [37], have been evaluated for a possible connection with ERa gene polymorphisms.

Our findings revealed a statistically significant difference between the two groups of mammographic density as the main risk factors for breast cancer that has been reported in previous studies. The risk of having HMD was increased in younger women, with a lower waist circumference, fewer pregnancies, a higher age at the first birth, and a high number of women with a family history of breast cancer. We observed that for the increase of 1 year in age, the probability of being classified as HMD as compared to controls, decreased $6.8 \%$. The groups of women with HMD were 56.31 years old in average, while in the controls group the average age was 58.16. This relationship was statistically significant $(p<0.001)$, indicating that younger women are most likely to have HMD. These findings are in agreement with the literature, showing decrease in breast density patterns with increasing age (Stomper et al. 1996 and Boyd et al. 2007). Among the avoidable risk factors throughout life, obesity/overweight are the most important ones, since they are the main determinants of the estrogen level in women after menopause [34] and; exposure to estrogens during life is a well established factor of increased risk for BC. According to recent studies, there is a positive relationship between BMI and breast cancer, especially in postmenopausal women [38-40]. Nevertheless, women with high BMI are less likely to have HMD, even though the risk for $\mathrm{BC}$ development increases in women with $\mathrm{HBD}$ and who are obese (obese, $\mathrm{OR}=1.7$ : obese $\mathrm{HBD}, \mathrm{OR}=2.01$ ) [41]. It is also suggested that for every $5 \mathrm{~kg}$ of weight gain in adult life, the risk of developing BC [42] increases by $8 \%$. Our data showed a high prevalence of obesity, but it was predominant in the control group (47.7\%). Obesity was highly prevalence in the HMD group (36.7\%), a surprising and worrying finding that deserves attention because of women with HBD, a factor considered as a high risk for developing $B C(R R>4.0)$.

Our findings revealed a statistically significant difference between the two groups of mammographic density also with respect to the distribution of the PvuII polymorphism genotype ( $p=0.024)$. It was found that women with two mutated alleles (homozygous mutant) had $76 \%$ greater chances of being diagnosed with HMD, compared to those with one or two normal alleles for this polymorphism (Table 4). The risk associated with the p allele of Pvull was shown to be an independent risk for other indicators of high exposure to endogenous estrogens. It was not observed any apparent effect modification for other indicators of exposure to endogenous estrogens and lifestyle factors. Similarly, van Duijnhoven et al. [17] studied the influence of ERa and HT on the $\mathrm{MD}$, reporting an association between increased MD and the presence of the mutated genotype $\mathrm{ER} \alpha-397(\mathrm{OR}=2.24)$ in women using HT when compared to those with wild genotype and not HT users. Parl et al. [30] found that the pp genotype of the PvullSNPs was higher in women with a diagnosis of BC at a younger age. Yaich et al. [9] examined the PvuII polymorphism in tumor tissue of 257 women with primary breast cancer and compared it to peripheral blood collected from 140 controls not affected by the disease. Women with BC and pp genotype had a diagnosis of $\mathrm{BC}$ at an earlier age compared with those with PP or Pp genotypes of the group that had cancer.

Investigating the genotype distribution of the XbaI polymorphism, 


\begin{tabular}{|c|c|c|c|c|c|c|}
\hline \multirow{2}{*}{\begin{tabular}{|l|} 
Independent variables \\
Constant
\end{tabular}} & \multirow{2}{*}{$\begin{array}{c}\text { B } \\
7.330\end{array}$} & \multirow{2}{*}{$\begin{array}{c}\text { Standard error B } \\
1.715\end{array}$} & \multirow[t]{2}{*}{ OR } & \multicolumn{2}{|c|}{ OR [IC 95\%] } & \multirow[t]{2}{*}{$\mathbf{p}$} \\
\hline & & & & & & \\
\hline Age & -0.070 & 0.025 & 0.932 & 0.888 & 0.979 & 0.005 \\
\hline WC & -0.038 & 0.011 & 0.963 & 0.943 & 0.984 & 0.001 \\
\hline Number of pregnancy & -0.186 & 0.069 & 0.830 & 0.725 & 0.950 & 0.007 \\
\hline Age at first birth & 0.052 & 0.025 & 1.053 & 1.004 & 1.106 & 0.035 \\
\hline FHBC & 0.707 & 0.335 & 2.028 & 1.052 & 3.909 & 0.035 \\
\hline Mutated Pvull & 0.562 & 0.290 & 1.754 & 0.993 & 3.099 & 0.053 \\
\hline
\end{tabular}

Table 5: Multiple logistic regression, stepwise backward method, where the dependent variable in the HMD and independent variables are: Age, BC, Number of Pregnancy, Age at first birth, HFBC, Mutated Pvull.

the authors found that women with two mutated alleles (homozygous mutant) were $30 \%$ more likely ( $\mathrm{OR}=1.31$ ) of having $\mathrm{HMD}$, though this difference was not significant $(\mathrm{p}=0.36)$. On the other hand, Andersen et al. [18], while investigating the allelic frequency of the PvuII and XbaISNPs in 360 cases of the $\mathrm{BC}$ and 672 controls, found significant differences only for the XbaI polymorphism. The $\mathrm{x}$ allele frequency among women with $\mathrm{BC}$ was $40 \%$ higher compared to that of the controls. In a case-control study conducted in South Korea by Shin et al. [6], the OR associated with the xx genotype of Xbal was 2.38 compared to the XX genotype. In that same vein, Cai et al. [10], in a large population study, found a significant association between of the PvuII polymorphism and $\mathrm{BC}(\mathrm{OR}=1.4)$. For XbaISNPs, the association of risk was 1.3 and only for women after menopause.

The molecular mechanisms through which these polymorphisms alter the receptor activity are not clear because PvuII and XbaI are located in an intronic, and apparently nonfunctional, region of the gene. Possible explanations include: (a) the existence of a functional combination between polymorphic alleles, where the two markers in combination would alter the gene function, as well as the RNAm stability [23]. Thus, this study investigated if the combination of PvuII and XbaI polymorphisms increased the risk of having HMD, and did not observe any synergistic effect between them; (b) Another explanation would be that polymorphisms in intron could have a Linkage Disequilibrium (LD) with the exon which would affect the function of the ER as a whole [37]; in this regard, it has been investigated whether polymorphisms in intron 1 are in LD with repeat polymorphism (GT)n located at $6627 \mathrm{bp}$ after the beginning of the transcription site of the exon 1 and to $144 \mathrm{~kb}$ before the exon 2; (c) Growth factors and their signaling molecules are important for cancer growth and its progression. There is considerable cross-talk between ER and growth factors such as insulin and IGF1 (growth factors like insulin), and the family of epidermal growth factors [43].

The allelic and genotypic frequencies obtained for the ER $\alpha-397$ PvuII polymorphism ( $\mathrm{P}=46.8 \%, \mathrm{p}=53.2 \%)$ were similar to those found in other studies in which this polymorphism was correlated with $\mathrm{MD}$ or BC $[11,13,17,19,27,29]$. The genotype distribution was in HardyWeinberg equilibrium with the following frequencies: pp genotype 29.0\%, Pp 48.5\% and PP 22.6\% (Table 4).

The allele frequencies for the Xbal polymorphism ( $\mathrm{x}=56.9 \%$, $\mathrm{X}=43.1 \%$ ) were lower when compared to two other studies conducted in Brazil [20,27], but they were in accordance with the frequency found by van Duijnhoven et al. [17], Molvarec et al. [28] and Hsieh et al. [29]. The genotype distribution for ER $\alpha-351$ XbaI was also in HardyWeinberg equilibrium with the following frequencies: $\mathrm{xx}$ genotype $31.6 \%$, Xx 50.4\% and XX 17.9\% (Table 4).

In relation to the independent variables that showed associationwith MD (age, race, WC, menarche, menopause, time after menopause, number of pregnancies, age atthe first birth, number of births, number of abortions, FH, BMI, alcohol intake, smoking and PvuII and XbaI genotypes), after performing a multiple logistic regression, only the clinical factors (age, WC, number of pregnancies, age at the $1^{\text {st }}$ birth, $\mathrm{FH}$ and PvuII polymorphism in the ERa) showed to be independent risk factors for HMD $(\mathrm{p}<0.05)$.

In summary, the present case-control study concluded that the $P v u I I$ polymorphism in the gene ERa was associated with an increased chance of having HMD, a factor of high risk for BC. Thus, recognizing these risk factors will be of great importance in the analyses of individual susceptibility to $\mathrm{BC}$; in both the study of the response to various drugs (for example HT) and the prognosis (Table 5).

\section{Footnote}

This research was supported by the Foundation for Research Support of the State of São Paulo (FAPESP)

\section{References}

1. Jensen EV, Jordan VC (2003) The estrogen receptor: a model for molecular medicine. Clin Cancer Res 9: 1980-1989.

2. Osborne CK, Schiff R (2005) Estrogen-receptor biology: continuing progress and therapeutic implications. J Clin Oncol 23: 1616-1622.

3. Greene GL, Gilna P, Waterfield M, Baker A, Hort Y, et al. (1986) Sequence and expression of human estrogen receptor complementary DNA. Science 231 1150-1154.

4. Souza MA, Fonseca AM, Bagnoli VR, Soares-Jr JM, Barros N, et al. (2012) Polimorfismo do gene do receptor estrogênico como fator de risco do câncer de mama. Femina 40: 179-186.

5. Boyapati SM, Shu XO, Ruan ZX, Cai Q, Smith JR, et al. (2005) Polymorphisms in ER-alpha gene interact with estrogen receptor status in breast cancer survival. Clin Cancer Res 11: 1093-1098.

6. Shin A, Kang D, Nishio H, Lee MJ, Park SK, et al. (2003) Estrogen receptor alpha gene polymorphisms and breast cancer risk. Breast Cancer Res Treat 80: 127-131.

7. Pharoah PD, Antoniou AC, Easton DF, Ponder BA (2008) Polygenes, risk prediction, and targeted prevention of breast cancer. N Engl J Med 358: 27962803.

8. Boyd NF (2011) Tamoxifen, mammographic density, and breast cancer prevention. J Natl Cancer Inst 103: 704-705.

9. Yaich L, Dupont WD, Cavener DR, Parl FF (1992) Analysis of the Pvull restriction fragment-length polymorphism and exon structure of the estrogen receptor gene in breast cancer and peripheral blood. Cancer Res 52: 77-83.

10. Cai Q, Shu XO, Jin F, Daí Q, Wen W, et al. (2003) Genetic polymorphisms in the estrogen receptor a gene and risk of breast cancer: results from the Shanghai Breast Cancer Study. Cancer Epidemiol Biomarkers Prev 12: 853859 .

11. Onland-Moret NC, van Gils CH, Roest M, Grobbee DE, Peeters PH (2005) The estrogen receptor alpha gene and breast cancer risk (The Netherlands) Cancer Causes Control 16: 1195-1202.

12. Shen Y, Li DK, Wu J, Zhang Z, Gao E (2006) Joint effects of the CYP1A1 Mspl, ERalpha Pvull, and ERalpha Xbal polymorphisms on the risk of breast cancer: results from a population-based case-control study in Shanghai, China. Cancer Epidemiol Biomarkers Prev 15: 342-347. 
Citation: Souza MA, Fonseca AM, Bagnoli VR, de Barros N, Hortense VHS, et al. (2013) Polymorphisms in the Estrogen Receptor Alpha Gene and Mammographic Density Result Study in Brazilian Women. J Cancer Sci Ther 5: 446-451. doi:10.4172/1948-5956.1000239

13. González-Mancha R, Galán JJ, Crespo C, Iglesias Pérez L, González-Perez A, et al. (2008) Analysis of the ERalpha germline Pvull marker in breast cancer risk. Med Sci Monit 14: CR136-143.

14. González-Zuloeta Ladd AM, Vásquez AA, Rivadeneira F, Siemes C, Hofman A, et al. (2008) Estrogen receptor alpha polymorphisms and postmenopausal breast cancer risk. Breast Cancer Res Treat 107: 415-419.

15. Crandall CJ, Sehl ME, Crawford SL, Gold EB, Habel LA, et al. (2009) Sex steroid metabolism polymorphisms and mammographic density in pre- and early perimenopausal women. Breast Cancer Res 11: R51.

16. Souza MA, Fonseca AM, Bagnoli VR, de Barros N, Franzolin SO, et al. (2013) Polymorphisms of estrogen receptor-a gene in Brazilian women with high breast density after menopause. Gynecol Endocrinol 29: 771-774.

17. van Duijnhoven FJ, Peeters PH, Warren RM, Bingham SA, Uitterlinden AG et al. (2006) Influence of estrogen receptor alpha and progesterone receptor polymorphisms on the effects of hormone therapy on mammographic density. Cancer Epidemiol Biomarkers Prev 15: 462-467.

18. Andersen TI, Heimdal KR, Skrede M, Tveit K, Berg K, et al. (1994) Oestrogen receptor (ESR) polymorphisms and breast cancer susceptibility. Hum Genet 94: $665-670$

19. Hu Z, Song CG, Lu JS, Luo JM, Shen ZZ, et al. (2007) A multigenic study on breast cancer risk associated with genetic polymorphisms of ER Alpha, COMT and CYP19 gene in BRCA1/BRCA2 negative Shanghai women with early onset breast cancer or affected relatives. J Cancer Res Clin Oncol 133: 969-978.

20. de Moura Ramos EH, Martinelli S, Silva I, Nazário A, Facina G, et al. (2009) Association between estrogen receptor gene polymorphisms and breast density in postmenopausal women. Climacteric 12: 490-501.

21. Dunning AM, Healey CS, Baynes C, Maia AT, Scollen S, et al. (2009) Association of ESR1 gene tagging SNPs with breast cancer risk. Hum Mol Genet 18: 1131-1139.

22. Javed S, Ali M, Sadia S, Aslam MA, Masood Al, et al. (2011) Combined effect of menopause age and genotype on occurrence of breast cancer risk in Pakistani population. Maturitas 69: 377-382.

23. Wedrén S, Lovmar L, Humphreys K, Magnusson C, Melhus H, et al. (2004) Oestrogen receptor alpha gene haplotype and postmenopausal breast cancer risk: a case control study. Breast Cancer Res 6: R437-449.

24. Wang J, Higuchi R, Modugno F, Li J, Umblas N, et al. (2007) Estrogen receptor alpha haplotypes and breast cancer risk in older Caucasian women. Breast Cancer Res Treat 106: 273-280.

25. Boyd NF (2013) Mammographic density and risk of breast cancer. Am Soc Clin Oncol Educ Book.

26. Herrington DM, Howard TD, Hawkins GA, Reboussin DM, Xu J, et al. (2002) Estrogen-receptor polymorphisms and effects of estrogen replacement on high-density lipoprotein cholesterol in women with coronary disease. $\mathrm{N}$ Engl J Med 346: 967-974.

27. Giacomazzi J (2008) Fatores de risco para o câncer de mama e polimorfismos nos genes ER, PR e STK15 em mulheres participantes de um programa de rastreamento mamográfico em Porto Alegre. Faculdade de Medicina da Universidade Federal do Rio Grande do Sul.

28. Molvarec A, Széplaki G, Kovács M, Széplaki Z, Fazakas A, et al. (2007) Estrogen receptor alpha (ESR1) Pvull and Xbal gene polymorphisms in ischemic stroke in a Hungarian population. Clin Chim Acta 382: 100-105.

29. Hsieh PC, Segers VF, Davis ME, MacGillivray C, Gannon J, et al. (2007) Evidence from a genetic fate-mapping study that stem cells refresh adult mammalian cardiomyocytes after injury. Nat Med 13: 970-974.

30. Parl FF, Cavener DR, Dupont WD (1989) Genomic DNA analysis of the estrogen receptor gene in breast cancer. Breast Cancer Res Treat 14: 57-64.

31. Weiderpass E, Persson I, Melhus H, Wedrén S, Kindmark A, et al. (2000) Estrogen receptor alpha gene polymorphisms and endometrial cancer risk. Carcinogenesis 21: 623-627.

32. Maruyama $\mathrm{H}$, Toji $\mathrm{H}$, Harrington $\mathrm{CR}$, Sasaki K, Izumi Y, et al. (2000) Lack of an association of estrogen receptor alpha gene polymorphisms and transcriptional activity with Alzheimer disease. Arch Neurol 57: 236-240.

33. Speer G, Cseh K, Winkler G, Vargha P, Braun E, et al. (2001) Vitamin D and estrogen receptor gene polymorphisms in type 2 diabetes mellitus and in android type obesity. Eur J Endocrinol 144: 385-389.

34. Souza MA, Fonseca Ade M, Bagnoli VR, Barros Nd, Neves EM, et al. (2014 The expression of the estrogen receptor in obese patients with high breast density (HBD). Gynecol Endocrinol 30: 78-80.

35. Kitawaki J, Obayashi H, Ishihara H, Koshiba H, Kusuki I, et al. (2001) Oestrogen receptor a gene polymorphismis associated with endometriosis, adenomyosis and leiomyomata. Hum Reprod 16: 51-55.

36. Massart F, Becherini L, Gennari L, Facchini V, Genazzani AR, et al. (2001) Genotype distribution of estrogen receptor-alpha gene polymorphisms in Italian women with surgical uterine leiomyomas. Fertil Steril 75: 567-570

37. Gennari L, Merlotti D, De Paola V, Calabrò A, Becherini L, et al. (2005) Estrogen receptor gene polymorphisms and the genetics of osteoporosis: a HuGE review. Am J Epidemiol 161: 307-320.

38. Ray A (2012) Adipokine leptin in obesity-related pathology of breast cancer. J Biosci 37: 289-294.

39. Morimoto LM, White E, Chen Z, Chlebowski RT, Hays J, et al. (2002) Obesity, body size, and risk of postmenopausal breast cancer: the Women's Health Initiative (United States). Cancer Causes Control 13: 741-751.

40. Baer HJ, Colditz GA, Rosner B, Michels KB, Rich-Edwards JW, et al. (2005) Body fatness during childhood and adolescence and incidence of breast cancer in premenopausal women: a prospective cohort study. Breast Cancer Res 7 : R314-325.

41. Davis AA, Kaklamani VG (2011) Metabolic Syndrome and triple-negative breast cancer: A new paradigm. International Journal Breast Cancer 1-10.

42. Boyd NF, Greenberg C, Lockwood G, Little L, Martin L, et al. (1997) Effects at two years of a low-fat, high-carbohydrate diet on radiologic features of the breast: results from a randomized trial. J Natl Cancer Inst 89: 488-496.

43. Burgering BM, Coffer PJ (1995) Protein kinase $B$ (c-Akt) in phosphatidylinositol3-OH kinase signal transduction. Nature 376: 599-602. 